\title{
INFLUENCE OF THE LIGHTING ON THE Portrait Photographs SHOT WITH THE Digital Photography System
}

\author{
Mikota, M.; PAVLOVIC, I. \& BROZOVIC, M.
}

Abstract: The paper deal with the digital photography system as the portrait technique. The possibilities for optimizing the system in the phase of shooting are pointed out. The influence of different type of studio portrait lighting on characteristics of color portrait photographs is analyzed. The analysis is carried out objectively with the comparison of total color differences of skin colors from taken and edited digital formats and subjectively with visual evaluation of skin colors and general sensation of the portraits. The research shows that even with the choosing the right white balance there are differences on the final photographs depending on the chosen lighting. For shooting with halogen and nitraphot lighting exposition correction is necessary for the adequate reproduction of skin colors and for the tungsten reflector lighting and flashlight that kind of correction is not necessary. With the made corrections all light sources give the quality color portrait photographs.

Key words: portrait photography, digital photography, skin colors, photographic lightings
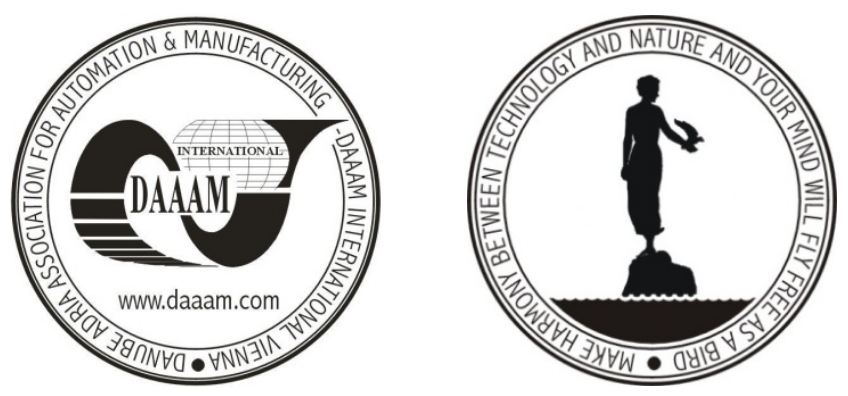

Authors' data: Dr. PhD. Mikota, M[iroslav]*; Ass. Pavlovic, I[vana]**; Dr. Brozovic, $\mathrm{M}[\mathrm{aja}]^{* * *}$, *Faculty of Graphic Arts, University of Zagreb, Zvonimirova 37, 10000, Zagreb, HR, ** Faculty of Graphic Arts, Stranička 18, 10430, Samobor, HR, *** Faculty of Graphic Arts, University of Zagreb, Horvacanska 41, 10000, Zagreb, HR, mmikota@grf.hr, ivana.pavlovic@grf.hr, mbrozovi@grf.hr

This Publication has to be referred as: Mikota, M[iroslav]; Pavlovic, I[vana] \& Brozovic, M[aja] (2008). Influence of the Lighting on the Portrait Photographs Shot with the Digital Photography System, Chapter 39 in DAAAM International Scientific Book 2008, pp. 463-476, B. Katalinic (Ed.), Published by DAAAM International, ISBN 9783-901509-66-7, ISSN 1726-9687, Vienna, Austria

DOI: $10.2507 /$ daaam.scibook.2008.39 